\title{
ANALISIS KEBIJAKAN SISTEM PEMUNGUTAN PAJAK REKLAME DI KOTA TOMOHON ( Studi Pada Dinas Pendapatan, Pengelolaan Keuangan dan Asset Kota Tomohon )
}

\author{
Christo A. Sualang1 \\ Ventje Ilat ${ }^{2}$ \\ Anneke Wangkar ${ }^{3}$ \\ Jurusan Akuntansi, Fakultas Ekonomi dan Bisnis, \\ Universitas Sam Ratulangi, Manado, 95115,Indonesia \\ Email: Christiosualang@gmail.com
}

\begin{abstract}
Advertisising tax collection system is essential in supporting the implementation of billboards orderly and neat and can create and atmosphere conducive bussines climate, public tranquility and public order can be realized. Therefore, if the better the organization and arrangement of adversement in the district/region, then the optimal well as local revenue from the tax sector. The purpose of this study was to determine policy adverstising tax collection system in the city tomohon and to determine obstacles in the collection of adversticement tax in tomohon. The data used in this research is secondary data is yhe data coming from the department of refenue, finance and asset management tomohon. The result showed that the adversment taxation system policy has not completely go according to the legislation in force. Planning policy and adversment tax voting system includes how the arrangement regarding the implementation, licensing, system and incidental arrangement permanent billboard, rental values and tax rates billboard, as well as system and procedures adverstisement taxation. Advertisement taxation obstacles in tomohon, among others: implementation of billboards not in accordance with the applicable local regulations and constraints in terms of licensing advertisement.
\end{abstract}

Keywords: policy, advertisement tax

\section{PENDAHULUAN}

Bangsa yang sukses terlihat dari kemampuan bangsa itu sendiri dalam meningkatkan kesejahteraan rakyatnya. Untuk meningkatkan kesejahteraan rakyatnya, maka dibutuhkan dana untuk pembiayaan pembangunan. Pembangunan nasional dewasa ini meliputi segala bidang dan tentunya perlu mendapatkan perhatian serius baik dari pihak pemerintah pada khususnya maupun masyarakat pada umumnya. Pembanguna itu sendiri hanya dapat dilaksanakan apabila ada dana yang tersedia. Dana tersebut dapat diperoleh dari berbagai sumber baik dari dalam maupun luar negeri, baik sektor suasta maupun pemerintah.

Salah satu penerimaan dari dalam negri adalah dari sektor pajak dalam bentuk pengabdian dan peran serta langsung masyarakat dalam rangka mengsukseskan pembangunan nasional, juga merupaklan salah satu bentuk pelayanan pemerintah kepada masyarakat. Pajak merupakan penghasilan Negara yang berasal dari rakyat dan merupakan sumber terpenting yang memberikan dana kepada Negara. Soemitro, dalam Mardiamo (2011) menyatakan bahwa pajak adalah iuran rakyat kepada kas Negara berdasarkan undangundang (yang dapat dipaksakan) dengan tiada mendapatkan jasa timbal (kontrapretasi) yang langsung dapat ditunjukan dan digunakan untuk membayar pengeluaran umum. Dalam rangka menyelenggarakan rumah tangganya sendiri pemerintah daerah memerlukan dana yang tidak sedikit, oleh karena itu pemerinta daerah harus mengoptimalkan sumber-sumber penerimaan daerah dalam era otonomi daerah. Pendapatan asli daerah (PAD) merupakan salah satu indikator yang menentukan derajat kemandirian suatu daerah.

Sumber Pendapatan Asli Daerah (PAD) merupakan sumber keuangan daerah yang digali dari dalam wilayah daerah yang bersangkutan. Proporsi Pendapatan Asli Daerah dalam seluruh penerimaan daerah masih rendah bila dibandingkan dengan penerimaan dari bantuan pemerintah pusat. Keadaan ini menyebabkan perlu dilakukan suatu upaya untuk menggali potensi keuangan daerah dalam peningkatan pendapatan daerah. Salah satu sumber utama Anggaran Pendapatan dan Belanja Negara yang mempunyai peranan penting dalam pembangunan adalah pajak daerah. 
Menurut Mardiasmo (2011) Pajak Daerah merupakan kontribusi wajib kepada Daerah yang terutang oleh orang pribadi atau badan yang bersifat memaksa berdasarkan Undang-Undang, dengan tidak mendapatkan imbalan secara langsung dan digunakan untuk keperluan daerah bagi sebesar-besarnya kemakmuran rakyat. Di dalam Peraturan Daerah tersebut terdapat jenis-jenis pajak yang dapat dipungut oleh Pemerintah Daerah. Pajak yang dipungut oleh Pemerintah salah satunya adalah Pajak Reklame. Pajak Reklame adalah pungutan yang dikenakan terhadap penyelenggaraan reklame.

Di Kota Tomohon sendiri, Pajak Reklame merupakan salah satu macam sumber penerimaan Pajak Daerah yang sangat penting dan termasuk salah satu pendapatan daerah yang memiliki kontribusi besar terhadap Anggaran Pendapatan Belanja Daerah (APBD) khususnya bagi pembangunan daerah Kota Tomohon. Dengan demikian diperlukan pengawasan yang baik oleh Pemerintah Kota Tomohon khususnya bagi Dinas Pendapatan Pengelolaan Keuangan dan Asset (DPPKA) dalam hal pemungutan pajak reklame.

Menganalisa setiap pembuatan reklame merupakan hal yang penting dalam menunjang penyelenggaraan reklame yang tertib dan rapi serta dapat menciptakan suasana kondusif dalam iklim usaha, ketentraman masyarakat dan ketertiban umum dapat terwujud. Oleh karena itu, apabila semakin baik pemungutan pajak reklame di wilayah kabupaten/kota, maka semakin optimal pula pendapatan asli daerah dari sektor pajak.

Berdasarkan latar belakang di atas, maka penulis mendapat ide untuk melakukan penelitian pada Dinas Pendapatan, Pengelolaan Keuangan dan Asset KotaTomohon dengan judul: "Analisis kebijakan sistem pemungutan pajak reklame di Kota Tomohon".

\section{Rumusan Masalah}

Berdasarkan atas beberapa hal yang telah diuraikan dalam latar belakang masalah, maka penulis merumuskan masalah yang menjadi dasar penyusunan skripsi yaitu bagaimana kebijakan dan apa saja kendala dalam sistem Pemungutan Pajak Reklame di Kota Tomohon.

\section{Tujuan Penelitian}

Tujuan yang ingin dicapai dalam penelitian ini adalah untuk mengetahui kebijakan Sistem Pemungutan Pajak Reklame di Kota Tomoohon dan Kendala dalam Pemungutan Pajak Reklame di Kota Tomohon.

\section{Definisi Akuntansi}

\section{TINJAUAN PUSTAKA}

Pajak adalah peralihan kekeyaan dari pihak rakyat kepada kas negara untuk membiayai pengeluaran rutin dan "surplus"-nya digunakan untuk public saving yang merupakan sumber utama untuk membiayai public investment (Siti Resmi 2011:1).

Pajak adalah iuran masyarakat kepada Negara (yang dapat dipaksakan) yang terutang oleh yang wajib membayarnya menurut peraturan-peraturan umum (undang-undang) dengan tidak mendapat prestasi kembali yang langsung dapat ditunjuk dan yang gunanya adalah untuk membiayai penyewaan umum berhubung tugas negara untuk menyelenggarakan pemerintahan (Diana Sari 2013:2).

Pajak mempunyai beberapa fungsi, yaitu sebagai berikut.

1. Fungsi Penerimaan (Budgetair)

2. Fungsi Mengatur (Regulared)

3. Fungsi Stabilitas

4. Fungsi Redistribusi

5. Fungsi Demokrasi

Menurut Mardiasmo ( 2011:6) Sistem pemungutan pajak terdiri atas tiga jenis, yaitu sebagai berikut.

1. Official Assessment System

2. Self-Assessment System

3. Withholding System

Menurut Rahayu (2010:50)Pengelompokan pajak terdiri dari tiga jenis, yaitu sebagai berikut.

1. Menurut Golongannya

2. Menurut Sifatnya

3. Menurut Lembaga Pemungutnya 
Aspek perpajakan menurut Waluyo (2011:3) terdiri dari empat aspek, yaitu sebagai berikut.

1. Aspek Ekonomi

2. Aspek Hukum

3. Aspek Keuangan

4. Aspek Sosiologi

Asas perpajakan menurut Mardiasmo ( 2011:6) terdiri dari tiga jenis, yaitu sebagai berikut.

1. Asas Domisili (Asas tempat tinggal)

2. Asas Sumber

3. Asas Kebangsaan

\section{Pajak Daerah}

Menurut Siahaan (2010) Pajak Daerah adalah iuran wajib yang di lakukan oleh pribadi atau badan kepada daerah tanpa imbalan langsung yang seimbang, yang dapat dipaksakan berdasarkan peraturan perundang-undangan yang berlaku yang digunakan untuk membiayai penyelenggaraan pemerintahan dan pembangunan daerah.

Menurut Siahaan (2010), ciri-ciri pajak daerah adalah sebagai berikut.

1. Pajak daerah merupakan setoran sebagian individu atau badan untuk kas Negara sesuai dengan ketentuan Undang-undang.

2. Sifat pemungutannya dapat dipaksakan dan tidak mendapat prestasi atau imbalan kembali secara langsung.

3. Penerimaan pajak oleh Negara dipakai untuk pengeluaran Negara dan melayani kepentingan masyarakat.

Pajak daerah menurut (Mardiasmo, 2011:13) dibagi menjadi 2 bagian, yaitu.

1. Pajak Provinsi terdiri dari.
a. Pajak Kendaraan Bermotor
b. Bea Balik Nama Kendaraan Bermotor
c. Pajak Bahan Bakar Kendaraan Bermotor
d. Pajak Air Permukaan
e. Pajak Rokok

2. Pajak Kabupaten/Kota terdiri dari
a. Pajak Hotel
b. Pajak Restoran
c. Pajak Hiburan
d. Pajak Reklame
e. Pajak Penerangan Jalan
f. Pajak Mineral Bukan Logam
g. Pajak Parkir
h. Pajak Air Tanah
i. Pajak Sarang Burung Walet
j. Pajak Bumi dan Bangunan Perdesaan dan Perkotaan
k. Bea Perolehan Atas Tanah dan bangunan

\section{Pajak Reklame}

Berdasarkan Peraturan Daerah Kota Tomohon No. 5 Tahun 2004 tentang Pajak Reklame, Pajak Reklame adalah iuran wajib yang dilakukan oleh pribadi atau badan kepada Daerah tanpa imbalan langsung yang seimbang atas penyelenggaraan reklame.

Dasar Hukum Pemungutan Pajak Reklame pada suatu kabupaten/kota adalah

1. Undang-Undang No.34 Tahun 2000 yang merupakan perubahan atas Undang-Undang No.18 Tahun 1997 tentang Pajak Daerah dan Retribusi Daerah

2. Peraturan Pemerintah Nomor 65 Tahun 2001 tentang Pajak Daerah

3. Pada Peraturan Daerah Kota Tomohon No. 5 Tahun 2004 tentang Pajak Reklame, Keputusan Walikota Tomohon Nomor 032004 tentang Pedoman Pelaksanaan Reklame yang kemudian dirubah dengan 
Keputusan Walikota Tomohon Nomor 4 Tahun 2007 tentang Pedoman Pelaksanaan Reklame, dan terakhir diperbaharui kembali dengan keputusan Walikota Tomohon Nomor 7 Tahun 2012.

Obyek Pajak Reklame adalah semua penyelenggaraan reklame, yaitu sebagai berikut.

1. Reklame papan atau billboard, megatron

2. Reklame kain

3. Reklame melekat (stiker)

4. Reklame selebaran

5. Reklame berjalan, termasuk pada kendaraan

6. Reklame udara

7. Reklame suara

8. Reklame peragaan

9. Reklame film atau slide

\section{Tata Cara Perijinan Pemasangan Reklame}

Berdasarkan pada Keputusan Walikota Tomohon Nomor 4 Tahun 2007 pasal 17 ayat (1), Surat permohonan ijin pemasangan reklame harus menguraikan keterangan-keterangan tentang.

1. Nama dan alamat Pemohon;

2) Jenis, bahan, perlengkapan reklame;

3) Ukuran reklame dan ketingggian reklame;

4) Bunyi, isi, naskah gambar atau foto reklame;

5) Tempat memasang reklame;

6) Posisi reklame yang akan dipasang;

7) Surat Kuasa dari perusahaan apabila permohonan reklame diserahkan kepada pihak lain

8) Keterangan-keterangan yang dianggap perlu.

9) Untuk reklame jenis billboard, papan atau sejenisnya harus disertakan pula gambar konstruksi reklame tersebut.

Pemasangan reklame harus mendapatkan persetujuan sebelumnya dari pihak yang berhak atau pihak bersangkutan.

1) Pemasangan reklame diatas tanah/gedung/bangunan milik dan/ atau yang dikuasai oleh Pemerintah/BUMN/BUMD harus melampirkan Surat Persetujuan dari Kepala Unit Kerja Instansi yang bersangkutan;

2) Pemasangan reklame diatas tanah/gedung/bangunan milik swasta/badan perorangan harus melampirkan Surat Persetujuan dari pemilik yang bersangkutan.

Pencabutan atas Ijin Reklame juga dapat dilakukan apabila.

1) Reklame yang bersangkutan ternyata tidak sesuai atau bertentangan dengan hal-hal yang disebutkan dalam Surat Ijin Pemasangan Reklame;

2) Pemegang Ijin tidak melakukan perawatan atau pemeliharaan atas reklame yang dipasang sehingga mengganggu kebersihan dan keindahan kota.

\section{Dasar Pengenaan dan Tarif Pajak Reklame}

Tarif Pajak Reklame ditetapkan sebesar 25\% (dua puluh persen) dari nilai sewa reklame. Besarnya pajak terutang dihitung dengan cara mengalikan tarif pajak dengan Dasar Pengenaan Pajak. Setiap penyelenggaraan reklame dikenakan Uang Jaminan Pembongkaran yang besarnya ditetapkan sebagai berikut:

1) $25 \%$ dari jumlah pajak yang harus dibayar untuk reklame tetap

2) $100 \%$ dari jumlah pajak yang harus dibayar untuk reklame incidental.

Terdapat pengecualian atas Uang Jaminan Bongkar yaitu.

1) Reklame film dan slide;

2) Reklame Suara;

3) Reklame Kendaraan;

4) Reklame Berjalan;

5) Reklame Peragaan;

6) Reklame lain yang penggunaannya secara tidak langsun menggunakan tanah yang dikuasai Pemerintah Daerah 


\section{Sistem Pemungutan Pajak Reklame}

Pajak Reklame merupakan satu-satunya Pajak Daerah yang system pemungutannya menggunakan Official Assesment System yaitu suatu sistem pemungutan yang memberi wewenang kepada pemerintah (fiskus) untuk menentukan besarnya pajak yang terutang oleh Wajib Pajak. Ciri-cirinya.

1) Wewenang untuk menentukan besarnya pajak terutang ada pada fiskus.

2) Wajib Pajak bersifat pasif.

3) Utang pajak timbul setelah dikeluarkan surat ketetapan pajak oleh fiskus.

\section{Jenis Penelitian}

\section{METODE PENELITIAN}

Jenis penelitian yang dilakukan adalah penelitian deskriptif.

\section{Tempat dan Waktu Penelitian}

Penelitian ini dilakukan di Dinas Pendapatan, Pengelolaan Keuangan dan Asset Kota Tomohon. Periode waktu penelitian dimulai dari akhir bulan Juli sampai dengan September 2015.

\section{Prosedur Penelitian}

langkah-langkah prosedur dalam penelitian, yaitu sebagai berikut.

1. Penulis melakukan kajian awal dengan melakukan studi literatur baik studi kepustakaan maupun membaca melalui internet.

2. Melakukan pengidentifikasian tentang masalah, merumuskannya, menetapkan tujuan/manfaat penelitian,

3. Membatasi masalah ke lingkup yang disesuaikan dengan penelitian saat ini.

4. Perancangan dan persiapan survai pada objek penelitian yang telah ditentukan,

5. Pengumpulan data baik primer maupun sekunder.

6. Melakukan pengolahan data, membahasnya kemudian menarik kesimpulan dan memberikan saran-saran guna melengkapi penelitian.

\section{Jenis Data}

Jenis data yang digunakan dalam penelitian ini adalah data kuantitatif. Menurut Effendi (2012: 145). ada 2 jenis data, yaitu.

1. Data kuantitatif: data yang disajikan dan diukur dalam suatu skala numerik atau dalam bentuk angkaangka.

2. Data kualitatif: data yang bersifat deskriptif atau berbentuk uraian atau penjelasan serta tidak dapat diukur dalam skala numerik. Namun karena dalam statistik semua data harus dalam bentuk angka, maka data kualitatif umumnya dikuantitatifkan agar dapat diproses lebih lanjut.

\section{Sumber Data}

Sumber data menurut Effendi (2012 : 148) dibedakan menjadi dua jenis yaitu.

1. Data primer

2. Data sekunder.

\section{Teknik Pengumpulan Data}

Teknik pengumpulan data yang digunakan penulis adalah antara lain sebagai berikut.

1. Penelitian Kepustakaan

Pengumpulan data dilakukan dengan mempelajari dan membaca buku-buku dari perpustakaan serta data lain yang mendukung dalam proses pembahasan masalah tersebut.

2. Penelitian Lapangan

Penelitian ini dilakukan melalui peninjauan langsung ke Dinas Pendapatan, Pengelolaan Keuangan dan Asset Kota Tomohon guna memperoleh data yang dibutuhkan dengan cara.

a. Dokumentasi

Mengumpulkan dokumen yang berkaitan dengan masalah yang akan dibahas serta kebijakankebijakan yang dikeluarkan.

b. Inquires of the client 
Metode penelitian ini dilakukan guna memperoleh informasi mengenai latar belakang dari objek penelitian seperti struktur organisasi, sejarah dari objek yang akan diteliti serta informasi lain yang berhubungan dengan penelitian.

c. Wawancara

Pengumpulan data ini dilakukan dengan melakukan tanya jawab baik dengan pimpinan maupun dengan pegawai yang berada di Dinas Pendapatan, Pengelolaan Keuangan dan Asset Kota Tomohon di bidang pajak daerah maupun di bidang perencanaan, pengendalian operasional guna memperoleh informasi yang lebih jelas mengenai masalah yang akan dibahas didalam penelitian.

\section{Definisi Operasional Variabel}

Definisi operasional variabel dalam penelitian ini adalah sebagai berikut.

1. Analisis kebijakan dalam penelitian ini yaitu.

a. Membuat pemeriksaan menjadi efektif dan efisien

b. Meningkatkan kinerja pemeriksaan pajak

c. Meningkatkan kepatuhan wajib pajak sebagai konsekuensi pemungutan pajak di Indonesia

d. Secara tidak langsung menjadi aspek pendorong untuk meningkatkan penerimaan Negara dari pajak.

2. Sistem pemungutan pajak dalam penelitian ini yaitu.

Bagaimana pemerintah dalam hal ini dinas pendapatan, pengelolaan keuangan dan asset (DPPKA) kota tomohon dalam menjalankan pemungutan pajak reklame tanpa ada kendalakendala dari pihak DPPKA Kota Tomohon sendiri maupun dari pihak penyelenggara reklame.

1. Pajak Reklame

Pajak reklame adalah iuran wajib yang dilakukan oleh pribadi atau badan kepada Daerah tanpa imbalan langsung yang seimbang atas penyelenggaraan reklame

\section{Metode Analisis}

Metode analisis yang digunakan dalam penelitian ini adalah analisis deskripsi. yaitu suatu metode pembahasan masalah yang sifatnya menguraikan, menggambarkan, membandingkan suatu data atau keadaan serta melukiskan dan menerangkan suatu keadaan sedemikian rupa sehingga dapatlah ditarik suatu kesimpulan.

\section{Deskripsi Objek Penelitian}

\section{HASIL PENELITIAN DAN PEMBAHASAN}

Dekade awal tahun 2000-an masyarakat di beberapa bagian wilayah kabupaten Minahasa melahirkan inspirasi dan aspirasi kecenderungan lingkungan strategis baik internal maupun eksternal untuk melakukan pemekaran daerah. Berhembusnya angin reformasi dan diimplementasikannya kebijakan otonomi daerah, semakin mempercepat proses akomodasi aspirasi masyarakat untuk pemekaran daerah dimaksud. Melalui proses yang panjang secara yuridis dan pertimbangan yang matang dalam rangka akselerasi pembangunan bangsa bagi kesejahteraan masyarakat secara luas, maka Pemerintah Kabupaten Minahasa beserta Dewan Perwakilan Daerah Kabupaten Minahasa merekomendasikan aspirasi masyarakat untuk pembentukan Kabupaten Minahasa Selatan, Kota Tomohon dan Kabupaten Minahasa Utara.

Terbentuknya lembaga legislatif Kota Tomohon hasil Pemilihan Umum Tahun 2004, menghasilkan Peraturan Daerah Kota Tomohon Nomor 22 Tahun 2005 tentang Lambang Daerah dan Peraturan Daerah Kota Tomohon Nomor 29 Tahun 2005 tentang Hari Jadi Kota Tomohon.

Kota Tomohon diresmikan oleh Menteri Dalam Negeri Hari Sabarno atas nama Presiden Republik Indonesia pada tanggal 4 Agustus 2003.

Saat ini Kota Tomohon terbagi menjadi 5 kecamatan, yaitu.

1. Tomohon Utara

2. Tomohon Tengah

3. Tomohon Timur

4. Tomohon Barat

5. Tomohon Selatan

Dinas Pendapatan Pengelolaan Keuangan dan Asset (DPPKA) Kota Tomohon tidak dapat dipisahkan dengan sejarah Kota Tomohon sebagai Daerah Otonom. Daerah Otonom yaitu daerah yang 
mengatur dan mengurus kepentingan rumah tangganya sendiri sebagaimana diatur dalam Undang-Undang Nomor 5 Tahun 1974 tentang Pokok-Pokok Pemerintahan Daerah.

Dinas Pendapatan Pengelolaan Keuangan dan Asset (DPPKA) Kota Tomohon mempunyai fungsi sebagaimana terdapat dalam Perda No.6 Tahun 1990 pasal 4 yaitu.

a. Merumuskan kebijakan teknis penyelenggaraan Pemerintahan Daerah di bidang pendapatan

b. Pengorganisasian atas pekerjaan penagihan Pajak Daerah, Retribusi Daerah, dan Pendapatan Asli Daerah lainnya serta kemasyarakatan Pajak Bumi dan Bangunan yang dilimpahkan kepada daerah.

c. Memberikan perijinan dan pelaksanaan pelayanan umum di bidang pendapatan daerah.

d. Penyusunan rencana kegiatan di bidang pendataan, penetapan, dan penghasilan Pajak Daerah, Retribusi Daerah dan Pendapatan Asli Daerah lainnya serta Pajak Bumi dan Bangunan.

e. Pembinaan terhadap Unit Pelaksanaan Teknis Dinas dan Cabang Dinas dalam lingkup Dinas Pendapatan.

f. Pengawasan dan Pengendalian di bidang pendataan, penetapan dan penagihan Pajak Daerah, Retribusi Daerah dan Pendapatan Asli Daerah lainnya serta Pajak Bumi dan Bangunan.

Dinas Pendapatan Pengelolaan Keuangan dan Asset (DPPKA) Kota Tomohon mempunyai tugas sebagai berikut.

a. Melaksanakan urusan Rumah Tangga Daerah dalam bidang Pendapatan Daerah dan tugas-tugas lainnya yang diserahkan oleh wali kota sesuai dengan ketentuan perundang-undangan yang berlaku.

b. Melakukan urusan tata usaha.

c. Melaksanakan pendaftaran dan pendataan Wajib Pajak Daerah dan Wajib Pajak Retribusi Daerah.

d. Melakukan penetapan Pajak Daerah dan Retribusi Daerah.

e. Membantu melakukan pekerjaan pendataan Objek dan Subjek Pajak Bumi dan Bangunan

f. Melakukan penyuluhan mengenai Pajak Daerah, Retribusi Daerah dan Pendapatan Asli Daerah lainnya serta Pajak Bumi dan Bangunan.

g. Melakukan koordinasi dan pengawasan atas pekerjaan penagihan Retribusi Daerah dan Pendapatan Asli Daerah lainnya

h. Melakukan pembukuan dan pelaporan atas pemungutan dan penyetoran Pajak Daerah, Retribusi Daerah dan Pendapatan Asli Daerah lainnya serta Pajak Bumi dan Bangunan.

i. Membantu melakukan penyampaian Surat Pemberitahuan Pajak Terutang (SPPT), Surat Ketetapan Pajak (SKP), Surat Pemberitahuan (SPT), dan sarana administrasi Pajak Bumi dan Bangunan lainnya

j. Melakukan tugas perencanaan dan pengendalian operasional di bidang pendapatan. penetapan dan penagihan Pajak Daerah, Retribusi Daerah, Pendapatan Asli Daerah dan Pajak Bumi dan Bangunan

\section{Hasil Penelitian}

Dalam hal kebijakan penataan reklame ini diperlukan adanya evaluasi kebijakan, seperti halnya menurut Dunn dalam Nugroho (2011:389) merumuskan evaluasi kebijakan sebagai suatu pemberian informasi mengenai kinerja atau memberikan hasil dari suatu kebijakan. Evaluasi digunakan untuk mempelajari tentang hasil yang diperoleh dalam suatu program untuk dikaitkan dalam pelaksanaannya, mengendalikan tingkah laku dari orang-orang yang bertanggungjawab terhadap pelaksanaan program, dan mempengaruhi respon dari mereka yang berada di luar lingkungan politik. Adapun kontribusi pajak reklame bagi Pendapatan Asli Daerah Kota Tomohon Tahun 2011 sampai tahun 2015.

\begin{tabular}{|c|c|c|c|}
\hline Tahun & PAD (Rp) & $\begin{array}{c}\text { Pajak Reklame } \\
(\mathbf{R p})\end{array}$ & $\begin{array}{c}\text { Kontribusi Pajak } \\
\text { Rerklame terhadap } \\
\text { PAD (\%) }\end{array}$ \\
\hline 2011 & 8.095 .029 .622 & 430.697 .510 & 5.32 \\
\hline 2012 & 11.241 .635 .125 & 284.668 .875 & 2.53 \\
\hline 2013 & 13.945 .339 .275 & 337.228 .375 & 2.42 \\
\hline 2014 & 18.417 .481 .822 & 362.960 .086 & 1.97 \\
\hline
\end{tabular}

Sumber : Dinas Pendapatan Pengelolaan Keuangan dan Asset Kota Tomohon

PAD Kota Tomohon setiap tahun mengalami penurunan, tahun 2011 sebesar 5.32\%, tahun 2012 menurun menjadi 2.53\%, tahun 2013 menjadi 2,42\% dan tahun 2014 menjadi 1,97\%. Penurunan kontribusi pajak 
reklami bagi PAD Kota Tomohon disebabkan karena Kurangnya atau tidak adanya kesadaran masyarakat sebagai wajib pajak untuk membayar pajak yang merupakan kendala dalam pemungutan pajak sehingga mengakibatkan berkurangnya penerimaan kas daerah.

\section{Pembahasan \\ Kebijakan Sistem Pemungutan Pajak Reklame di Kota Tomoohon}

Kebijakan mengenai penyelenggaraan reklame merupakan suatu hal yang harus dipatuhi oleh penyelenggara reklame. Dinas Pendapatan Pengelolaan Keuangan dan Asset (DPPKA) Kota Tomohon dalam membuat kebijakan penyelenggaraan reklame harus bersifat mengikat bagi seluruh penyelenggara reklam. Hal ini didukung oleh kebijakan publik menurut Nugroho (2011 : 1-7) yakni kebijakan penyelenggaraan reklame harus bisa mengatur, ditaati dan bersifat mengikat bagi semua penyelenggara reklame, setiap pelanggaran akan diberikan sanksi bila tidak sesuai dengan kebijakan yang telah ditetapkan. Berdasarkan teori di atas, kebijakan terhadap penyelenggaraan reklame yang diterapkan oleh bidang pendapatan DPPKA Kota Tomohon harus bisa menjadi acuan bagi seluruh proses dan pelaksanaan penyelenggaraan reklame yang ada di daerah.

Kebijakan mengenai ketentuan perizinan reklame merupakan perihal yang harus dilalui oleh penyelenggara reklame sebelum mereka menyelenggarakan reklame mereka dan ini berpedoman pada peraturan daerah nomor 4 tahun 2006 tentang penyelenggaraan reklame. Sama halnya dengan penyelenggaraan reklame, kebijakan mengenai perizinan reklame yang dibuat oleh Dinas Pendapatan Pengelolaan Keuangan dan Asset harus bisa berkaitan dengan perundang-undangan yang berlaku. Seperti halnya menurut Menurut Wahab (2011 :4-5) istilah public policy seringkali penggunaannya saling ditukarkan denganistilah-istilah lain seperti tujuan (goals) program, keputusan, undang-undang,ketentuanketentuan, usulan-usulan dan rancangan-rancangan besar.

Sistem pemungutan pajak Reklame merupakan bagian dari kegiatan administrasi publik sebab memiliki cara dan ketentuan yang berhubungan dengan setiap penyelenggara reklame dan objek reklame mereka. Peran administrasi menjadi sangat penting dalam sistem pengelolaan reklame permanen dan insidentil ini, dibentuknya bidang pendapatan DPPKA diharapkan mampu memecahkan masalah yang ada dalam penataan jenis reklame ini seperti halnya menurut Widjaja $(2013$ :.4) "peranan administrasi publik tidak cukup hanya dalam konsep dan teori semata, tetapi benar-benar dapat mewujudkan suatu disiplin ilmu (ilmu administrasi) yang mampu memecahkan masalah yang semakin kompleks dan rumit, khususnya dalam pelaksanaan penyelenggaraanan otonomi daerah".

Sistem pemungutan pajak reklame permanen dan insidentil salah satunya berpedoman pada peraturan daerah nomor 7 tahun 2012 tentang pajak daerah yang mana menyebutkan masa pajak baik reklame permanen dan reklame insidentil. Dalam perda tersebut pasal 40 dijelaskan bahwa Masa Pajak Reklame adalah jangka waktu yang sama dengan masa penyelenggaraan reklame yang ditentukan sebagai berikut: Dalam hal reklame diselenggarakan secara permanen, masa pajak adalah waktu yang lamanya 1 (satu) tahun, sedangkan dalam hal reklame diselenggarakan dalam waktu terbatas dikategorikan sebagai reklame insidentil, masa pajak ditetapkan 1 (satu) bulan, 1 (satu) minggu, dan 1 (satu) hari. Dalam penelitian juga menyebutkan bahwa masa pajak reklame insidentil paling lama selama 3 bulan dan itu bisa diperpanjang. Selain itu, dari hasil penelitian di lapangan, pengelolaan reklame permanen dan insidentil di kota Tomohon adalah dilihat dari segi bahan yang digunakan, dimana reklame permanen menggunakan bahan yang bisa tahan lama, sedangkan reklame insidentil menggunakan bahan yang biasanya tidak tahan lama. Dari kedua jenis reklame diatas berhubungan erat dengan masa pajak reklame tersebut.

Ketentuan nilai sewa reklame yang dibebankan kepada wajib pajak oleh Dinas Pendapatan Pengelolaan Keuangan dan Asset berpedoman pada perda nomor 7 tahun 2012 pasal 24 tentang pajak daerah dan tentang penyelenggaraan reklame, penetapan tarif pajak reklame juga sesuai dengan perda nomor 7 tahun 2012 pasal 27 yang menyebutkan bahwa tarif pajak reklame ditetapkan sebesar 25\% (dua puluh lima persen) dari nilai sewa reklame.

Dalam melaksanakan pemungutan pajak reklame, bidang pendapatan DPPKA Kota Tomohon menerapkan Sistem Official Assesment, dimana penetapan besarnya pajak terutang ditetapkan oleh dinas. Sesuai dengan pendapat Mardiasmo (2011 : 7) sistem yang digunakan adalah Official assessment system. Dalam sistem ini menjelaskan besarnya pajak terutang di tetapkan dinas yaitu DPPKA, sedangkan wajib pajak reklame bersifat pasif dan hanya menunggu dikeluarkannya surat ketetapan pajak daerah oleh Dinas. 
Sedangkan prosedur pemungutan Pajak Reklame yang diterapkan di Kota Tomohon adalah melalui beberapa tahapan, yaitu.
a) Pendaftaran,
b) Pendataan,
c) Penetapan Besarnya Pajak Terutang Reklame, dan
d) Penagihan dan Pembayaran Pajak Reklame.

\section{Kendala dalam Pemungutan Pajak Reklame di Kota Tomohon}

1. Penyelenggaraan Reklame Belum Sesuai Dengan Peraturan Daerah Yang Berlaku.

Salah satu kendala yang muncul dalam proses pemungutan pajak reklame adalah kurangnya kesadaran dari penyelenggara reklame dalam mematuhi praturan yang di buat oleh pemerintah daerah tentang tata cara penyelenggaraan reklame karena tanpa kesadaran dari penyelenggara reklame system pemungutan pajak reklame akan banyak mengalami kendala-kendala. Dalam pelaksanaanya di Kota Tomohon masih sering terjadi hal-hal yang masih tidak sesuai dengan peraturan daerah yang ada seperti dalam hal pembongkaran reklame yang mana penyelenggara reklame tidak tepat waktu dalam pembongkaran objek reklamenya setelah masa izin mereka habis, padahal sesuai dengan perda nomor 4 tahun 2007 pasal 7 dijelaskan bahwa penyelenggara reklame berkewajiban membongkar reklame beserta bangunan konstruksi segera setelah berakhir izin atau setelah izin dicabut.

2. Kendala Dalam Hal Perizinan Reklame

Proses penerapan pemungutan pajak reklame di kota tomohon belum sesuai dengan peraturan daerah yang berlaku, seperti pada perda Nomor 4 Tahun 2007 pasal 16-17 bahwa setiap reklame baru dapat dipasang setelah mendapatkan ijin terlebih dahulu dari walikota melalui kepala dinas pendapatan,pengelolaan keuangan dan asset kota tomohon. Tetapi dari hasil temuan di lapangan masih ada beberapa kendala yang muncul dimana masih banyak penyelenggara reklame yang memasang reklamenya terlebih dahulu tetapi belum meminta izin kepada DPPKA Kota Tomohon untuk memasang reklame. Hal itu disebabkan waktu dan presodur yang terlalu lama dan sulit untuk dijalankan oleh penyelenggara reklame.

3. Kurangnya Kesadaran Dari Wajib Pajak Untuk Mendaftarkan dan Membayar Pajak Reklame

Karakteristik Responden

Kurangnya kesadaran wajib pajak merupakan kendala utama dalam proses pemungutan pajak, sehingga mengakibatkan berkurangnya penerimaan kas daerah (APBD). Sesuai dengan Mardiasmo (2011:8) yang mana ada perlawanan pasif yang dilakukan wajib pajak reklame dimana enggan (pasif) dalam membayar pajak, mungkin dikarenakan sistem perpajakan yang sulit dipahami oleh wajib pajak reklame dan sistem kontrol yang tidak dapat dilaksanakan dengan baik. Sehingga banyak reklame-reklame yang sudah di pasang di dalam kota tomohon tetapi belum terdaftar sebagai reklame aktif di DPPKA kota tomohon, walaupun telah diketahui bahwa pemasangan reklame yang dilakukan tanpa ijin terlebih dahulu dari walikota melalui kepala DPPKA kota tomohon, dikenakan sanksi tambahan pajak sebesar 100\% dari pokok pajak dan sanksi pidana sebagaimana diatur dalam Pasal 36 Peraturan Daerah No. 4 Tahun 2007 tentang Pajak Daerah.

\section{Kesimpulan}

\section{PENUTUP}

Dari hasil pengolahan data dan pembahasan dalam penelitian ini dapat ditarik kesimpulan berupa.

1. Kebijakan sistem pemungutan pajak reklame belum sepenuhnya berjalan sesuai sistem dan prosedur yang berlaku. Kebijakan Sistem Pemungutan pajak reklame meliputi bagaimana penyelenggaraan dan perizinan, system sewa dan tarif pajak reklame, serta prosedur pemungutan pajak reklame.

2. Kendala dalam pemungutan pajak reklame Kota Tomohon, antara lain: system pemungutan pajak reklame belum sesuai dengan peraturan daerah yang berlaku dalam hal perizinan penyelenggaraan reklame, kurangnya kesadaran dari wajib pajak untuk mendaftarkan dan membayar pajak.

\section{Saran}

Berdasarkan hasil penelitian dan pembahasan di atas, maka penulis memberi saran sebagai berikut.

1. Adanya pengawasan dan tanggung jawab yang dilakukan oleh DPPKA dalam proses pelaksanaan penyelenggaraaan reklame di Kota Tomohon, dan disarankan harus meningkatkan kegiatan sosialisasi di 
setiap daerah baik kepada wajib pajak yang telah terdaftar maupun belum terdaftar bahwa mantaati peraturan dalah hal membayar pajak sangat baik bagi kedua belah pihak, diharapkan juga lebih mengerti atau paham atau aktif terhadap pedoman atau acuan perda yang menyangkut system pemungutan pajak reklame.

2. Mengoptimalkan pemungutan pajak reklame dengan memberikan sosialisasi terhadap wajib pajak agar mempunyai tanggung jawab untuk melaporkan data reklamenya secara jujur dan berperan aktif dalam mendaftarkan objek reklamenya, tidak hanya bergantung pada DPPKA maupun petugas UPTD yang terkait.

\section{DAFTAR PUSTAKA}

Mardiasmo. 2011. Perpajakan Indonesia, Edisi Revisi 2011 . Yogyakarta, Penerbit ANDI

Siti Resmi, 2011. Perpajakan (teori dan kasus), Edisi 6, Salemba Empat, Jakarta.

Diana Sari.2013. Konsep Dasar Perpajakan. Bandung: PT Refika Adimata

Rahayu, Siti Kurnia, 2010, Perpajakan Indonesia, Graha Pustaka, Yogyakarta.

Waluyo, 2011, Perpajakan Indonesia, Edisi 10, Salemba Empat, Jakarta.

Pahala Siahaan Marihot, 2010, Pajak Daerah dan Retribusi Daerah, Edisi 1, PT. Raja Grafindo Persada,Jakarta.

Effendi, Sopian dan Tukiran 2012. Metode penelitian. Jakarta : Yahysa

Nugroho, Riant. 2011. Public policy: Dinamika Kebijakan, Analisis Kebijakan, Manajemen

Kebijakan . Jakarta, Gramedia

Abdul Wahab dan Umiarsa. 2011. Kependidikan dan kecerdasan spiritual. Yogyakarta: Ar-Ruzz

Widjaja, HAW. 2013. Penyelenggaraan Otonomi Di Indonesia. Jakarta, PT Raja Grafindo Persada

Peraturan Daerah Kota Tomohon No. 5 Tahun 2004 tentang Pajak Reklame

Peraturan Daerah Kota Tomohon Nomor 4 Tahun 2007 pasal 16-17tentang perijinan penyenggaraan reklame

Undang-Undang Nomor 5 Tahun 1974 tentang Pokok-Pokok Pemerintahan Daerah.

Peraturan Daerah Kota Tomohon nomor 7 tahun 2012 pasal 27 tentang penetapan tarif pajak reklame juga sesuai dengan

Peraturan Daerah Kta Tomohon nomor 4 tahun 2007 pasal 7, tentang pembongkatan reklame

Peraturan Daerah No. 4 Tahun 2007 pasal 36, tentang Pajak Daerah. 